Samoilyk Iuliia Vasylivna

Doctor of Economics, Associate Professor, Associate Professor of the Department of Enterprises Economy, Poltava State Agrarian Academy, Poltava, Ukraine

Orcid ID: 0000-0003-1335-2331 iuliia.samoilyk@gmail.com

Svystun Lyudmyla Anatoliivna Candidate of Economics, Associate Professor, Associate Professor of the Department of Finance and Banking, Poltava National Technical Yuri Kondratyuk University, Poltava, Ukraine

Orcid ID: 0000-0002-6472-9381 svmila308@gmail.com

\title{
THE PROSPECTS OF THE LEVEL INCREASE OF RURAL HOUSING ENERGY EFFICIENCY
}

The proposals to increase the energy efficiency level of housing have been further developed. For the first time, comprehensive research of the volume of the rural building in relation with the energy-saving potential in this sphere has been conducted, based on foreign experience and the proposals regarding alternative energy development. Trends and proportions of urban and rural development have been identified. Diagnostics of energy consumption indicators in rural houses in by Ukrainian regions have been made. Volumes and cost of energy consumption indicators in the city and in the countryside have been calculated. The mechanism of energy audit has been proposed. The role of energy consumptions actors at the state and local levels has been justified. Directions for level energy efficiency increase in rural houses have been suggested.

Key words: energy efficiency, energy consumption, rural houses, energy audit, energyefficient renovation

Introduction. One of the world's major problems is the issue of energy efficiency and energy saving. The level of energy consumption in Ukraine is three times higher than in EU countries. According to government estimates, the energy consumption in the Ukraine could be reduced by almost half through the introduction of energy efficient technologies in industry and the residential sector. Therefore, the potential for the development of efficient energy use, particularly in the field of real estate exploitation, is very high.

Ukraine has been an outdated housing fund with a high degree construction period of $1950 \mathrm{~s}$ and 1970s. The building lose third of the heat, because the walls and windows are not hermetic, the buildings have significant disadvantages in the roof's waterproofing; long-term operation has been led to the demolition of utility networks. Energy consumption of housing and communal services is $31 \%$. This requires defining the directions of housing reconstruction on the basis of improving its energy efficiency and energy saving. The building, which consumes less energy to provide greater comfort conditions, is more energy efficient. Therefore, under the current conditions of rising energy costs, the using of alternative energy and energy-efficient technologies for home heating has been very relevant.

Literature review. Research of energy efficiency and energy saving in the economy has been covered in the works of such scholars as: V. Barannik, V. Geyets, S. Yermilov, O. Sukhodolia, O. Ovsienko, V. Mykytenko, S. Denysyuk [1-5] and other Ukrainian and foreign scientists. The 
authors explore the rational and conscious use of available energy resources for their careful preservation. Mykytenko V. and O. Sukhodolia [3,4] study tools and spheres of energy efficiency state regulation. Success factors for energy saving policy have been considered in the works by S. Denysyuk [5]. The problems of energy efficiency and energy saving in the housing sector have been engaged by such economists: M. Villca-Pozo, H. Elsharkawy and P. Rutherford, B. SerranoLanzarote, I.G. Hamilton, B.Coyne, R.Lawrence and C.Keime, B.Lin, V.Brigilevich, V.Volkov, T. Zavora, G. Kopets [6-14]. In particular, the studies of Spanish scientists regarding the quantitative determination of the energy saving potential in the Spanish housing fund, the formation of a strategy for its energy renewal and the introduction of tax benefits for the modernization of energy efficiency in housing in Spain are interest $[11,12]$. H. Elsharkawy and P. Rutherford present the results from an extensive pre- and post-retrofit home energy use and performance survey of 150 properties located in Nottingham's Aspley. Their research seeks to inform and improve the uptake and delivery of future housing retrofit initiatives [10].

The reasons for the high level of energy consumption in Ukrainian housing have been covered in the work by T. Zavora, L. Svystun, Y. Khudolii [13]. Many Ukrainian scientists study foreign experience of improving the energy efficiency in housing and technologies of rehabilitation and construction of energy efficient buildings. The authors also have been analyzed the financial mechanisms of energy-efficient housing reconstruction [14]. The issue of construction efficiency has been little explored in rural areas. This issue has been partially explored in our work [15], but needs further investigation taking into account current trends in the energy and construction spheres.

The purpose of the article has been proposals justification to increase the rural houses energy efficiency level, identify the potential of energy efficiency in rural areas, identify differences in energy consumption in the countryside and in the city.

Results and discussion. At the beginning of 2019, the housing of Ukraine has been amounted to 993.2 million $\mathrm{m}^{2}$ of total area. The housing fund of rural settlements has been accounted for $39.1 \%$ of the total. Estimation of the statistics in the dynamics by years shows a decrease in the total living space of the housing from 1079.5 million $\mathrm{m}^{2}$ in 2010 to 993.3 million $\mathrm{m}^{2}$ in 2018 . This has been due to subjective reasons, namely: military actions in eastern Ukraine, and consequently, destruction of the housing and failure to include in the statistical information the full amount of this data. However, since 2014, there has been an increase in the housing, namely by 27.2 million $\mathrm{m}^{2}$ or by $2.8 \%$ (Fig. 1 ).

Square, m2 Proportion, \%

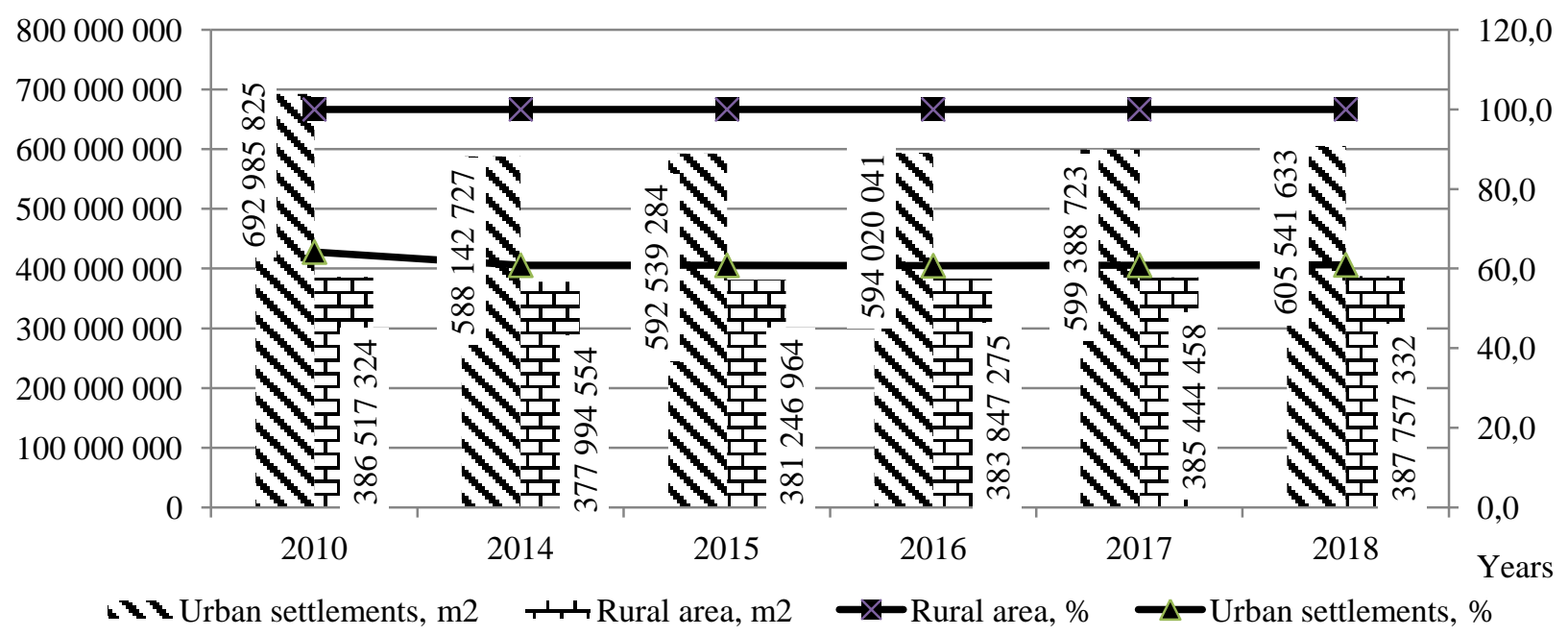

Fig. 1. Housing allocation by urban and rural areas

Source: summarized by the authors on based [16-22]. 
The share of rural housing has been increase from 386.5 million $\mathrm{m}^{2}$ in 2010 , or $35.8 \%$ of the total housing to 387.8 million $\mathrm{m} 2$ in 2018 , or $39 \%$; compared to 2014 , the rural housing have been increased by 9.76 million $\mathrm{m}^{2}$, or $2.6 \%$, which has been a positive trend. Rural displacement has been uneven in Ukraine. The share of rural housing has been higher in the western regions and ranges from $14.06 \%$ in Donetsk and $19.48 \%$ in Dnipropetrovsk regions to $63.08 \%$ in Zakarpattia. According to the State Statistics Committee, almost all housing $(98.2 \%)$ has housed in apartment buildings; the square of dormitories and residential premises in non-residential buildings has been totaled $1.8 \%$ (Table 1).

Table 1

The total area of residential premises, sq.m

\begin{tabular}{|l|c|c|c|c|c|c|c|c|}
\hline Regions of Ukraine & 2010 & 2011 & 2015 & 2016 & 2017 & 2018 & $\begin{array}{c}2018 \text { to } \\
2010,+,-\end{array}$ & $\begin{array}{c}2018 \text { to } \\
2010, \%\end{array}$ \\
\hline Ukraine & 372895,1 & 390490,0 & 381247,0 & 383847,3 & 3854444,5 & 387757,3 & 14862 & 4,0 \\
\hline Vinnytsia & 27602,5 & 27493,7 & 27585,3 & 27553,1 & 27566,9 & 27589,1 & -13 & 0,0 \\
\hline Volyn & 12044,8 & 12235,5 & 12759,6 & 12937,0 & 13123,3 & 13299,2 & 1254 & 10,4 \\
\hline Dnepropetrovsk & 14963,2 & 14956,9 & 14993,3 & 14999,6 & 15005,1 & 14988,2 & 25 & 0,2 \\
\hline Donetsk & 10493,8 & 10552,3 & 6885,1 & 7229,8 & 7244,9 & 7247,4 & -3246 & $-30,9$ \\
\hline Zhytomyr & 16751,2 & 16828,6 & 16987,6 & 17021,4 & 17052,7 & 17102,2 & 351 & 2,1 \\
\hline Zakarpatia & 18282,8 & 18653,4 & 19271,6 & 19376,4 & 19471,4 & 19617,6 & 1335 & 7,3 \\
\hline Zaporozhye & 10992,8 & 11005,0 & 11054,7 & 11059,6 & 11085,3 & 11081,5 & 89 & 0,8 \\
\hline Ivano-Frankivsk & 19316,8 & 19599,1 & 20990,3 & 21056,6 & 21462,7 & 21666,6 & 2350 & 12,2 \\
\hline Kiev & 27160,2 & 27640,4 & 30916,1 & 31760,3 & 32228,7 & 32806,8 & 5647 & 20,8 \\
\hline Kirovohrad & 10452,4 & 10422,4 & 10361,5 & 10366,0 & 10350,9 & 10338,9 & -113 & $-1,1$ \\
\hline Lugansk & 7753,9 & 7779,1 & 5219,8 & 5222,4 & 5222,5 & 5231,0 & -2523 & $-32,5$ \\
\hline Lviv & 24396,5 & 24857,7 & 26307,2 & 26626,9 & 26838,4 & 27113,2 & 2717 & 11,1 \\
\hline Mykolaiv & 8906,8 & 8856,9 & 8846,7 & 8855,0 & 8861,8 & 8865,2 & -42 & $-0,5$ \\
\hline Odessa & 20493,8 & 21243,8 & 21710,2 & 22010,3 & 22121,9 & 22436,4 & 1943 & 9,5 \\
\hline Poltava & 16909,6 & 16902,9 & 16976,3 & 16986,1 & 16987,3 & 16988,1 & 78 & 0,5 \\
\hline Rivne & 14046,0 & 14192,6 & 14770,3 & 14920,8 & 15072,0 & 15228,9 & 1183 & 8,4 \\
\hline Sumy & 10645,9 & 10669,4 & 10818,7 & 10826,4 & 10818,9 & 10794,7 & 149 & 1,4 \\
\hline Ternopilska & 15050,7 & 15192,2 & 15703,5 & 15770,9 & 15851,5 & 15929,7 & 879 & 5,8 \\
\hline Kharkiv & 13849,3 & 14123,3 & 14261,9 & 14279,5 & 14233,0 & 14248,0 & 399 & 2,9 \\
\hline Kherson & 9444,5 & 9474,8 & 9548,1 & 9556,1 & 9300,5 & 9529,5 & 85 & 0,9 \\
\hline Khmelnytsky & 18015,5 & 18127,9 & 18327,5 & 18347,3 & 18365,1 & 18385,5 & 370 & 2,1 \\
\hline Cherkasy & 17992,2 & 18178,0 & 18438,1 & 18454,3 & 18457,4 & 18479,6 & 487 & 2,7 \\
\hline Chernivtsi & 12685,7 & 12908,6 & 13643,1 & 13745,5 & 13826,0 & 13881,6 & 1196 & 9,4 \\
\hline Chernihiv & 14644,4 & 14767,2 & 14870,6 & 14885,9 & 14896,2 & 14908,4 & 264 & 1,8 \\
\hline
\end{tabular}

Source: summarized by the authors on based [16-22].

The rural housing dynamics analysis has been shown that rural housing the most significant increase during 2010-2018 in the Kyiv region - from 27.16 million $\mathrm{m}^{2}$ in 2010 to 32.8 million $\mathrm{m}^{2}$, or $20.8 \%$; in the Volyn region - from 12 million $\mathrm{m}^{2}$ in 2010 to 13.3 million $\mathrm{m}^{2}$, or $10.4 \%$; IvanoFrankivsk - by 2.35 million $\mathrm{m}^{2}$, or $12.2 \%$; Lviv - by 2.7 million $\mathrm{m}^{2}$, or $11.1 \%$; Odessa - by 1.9 million $\mathrm{m}^{2}$, or $9.5 \%$; Chernivtsi - by 1.2 million $\mathrm{m}^{2}$, or by $9.4 \%$. The increase in rural development in Western Ukraine has been primarily due to the region geographical features. Most of these regions buildings have been belonged to the rural area. Large parts of the population of these areas work in other countries and invest their money in the construction of private homes. Similar trends have been also observed in the Odessa region. The region has considerable territorial and economic potential to increase the rural housing. The Kiev region is the capital city and therefore has a higher investment potential comparatively with other regions of Ukraine. As a consequence, the volume of rural housing development has been increased in accordance with the region's socio-economic growth (Fig. 2). Therefore, the leader in housing square in rural settlements has been the Kyiv region -32.8 million $\mathrm{m}^{2}$, and also the leaders in housing square have been Vinnytsia, Lviv, Odesa and Ivano-Frankivsk regions with a housing square of more than 20 million $\mathrm{m}^{2}$ in each region. These regions have an average share of this housing square kind in total housing square (approximately $50 \%$ ). The smallest living area in rural areas is Kherson, Mykolaiv, Donetsk, Luhansk regions with an area of less than 10 million $\mathrm{m}^{2}$. 
Share, $\%$

Square, $\mathrm{m} 2$

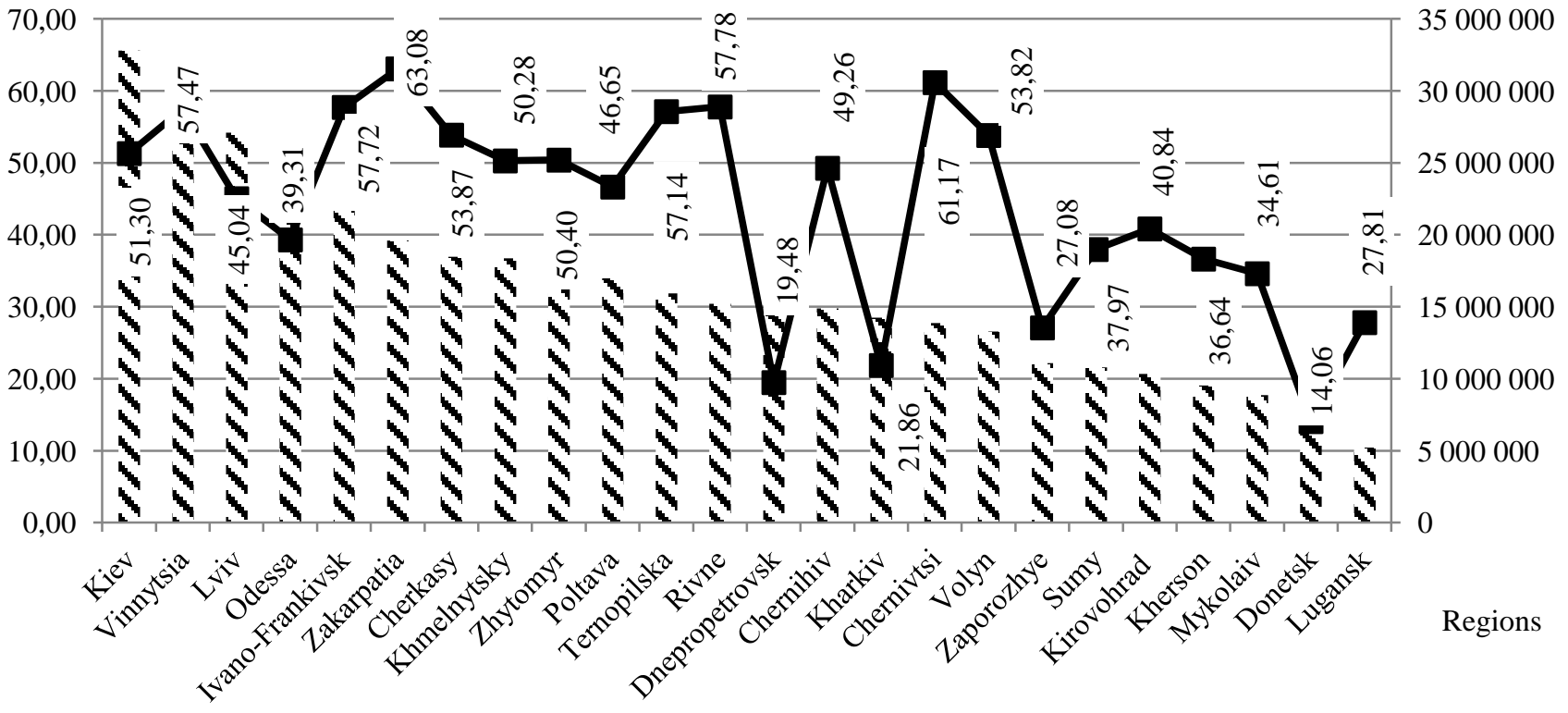

Fig. 2. Rating of the Ukraine regions by the rural housing square $\left(\mathrm{m}^{2}\right)$ and its share in the total housing square of Ukraine (\%)

Source: summarized by the authors on based [16, 23].

The housing classification by years of development (Fig. 3) has been shown in, that about half of the housing has been put into operation in the postwar years and in the first period of industrial buildings (until 1970). A significant proportion of the country's housing, home to about $50 \%$ of the population, has been in a state of disrepair or outdated and needs major overhaul.
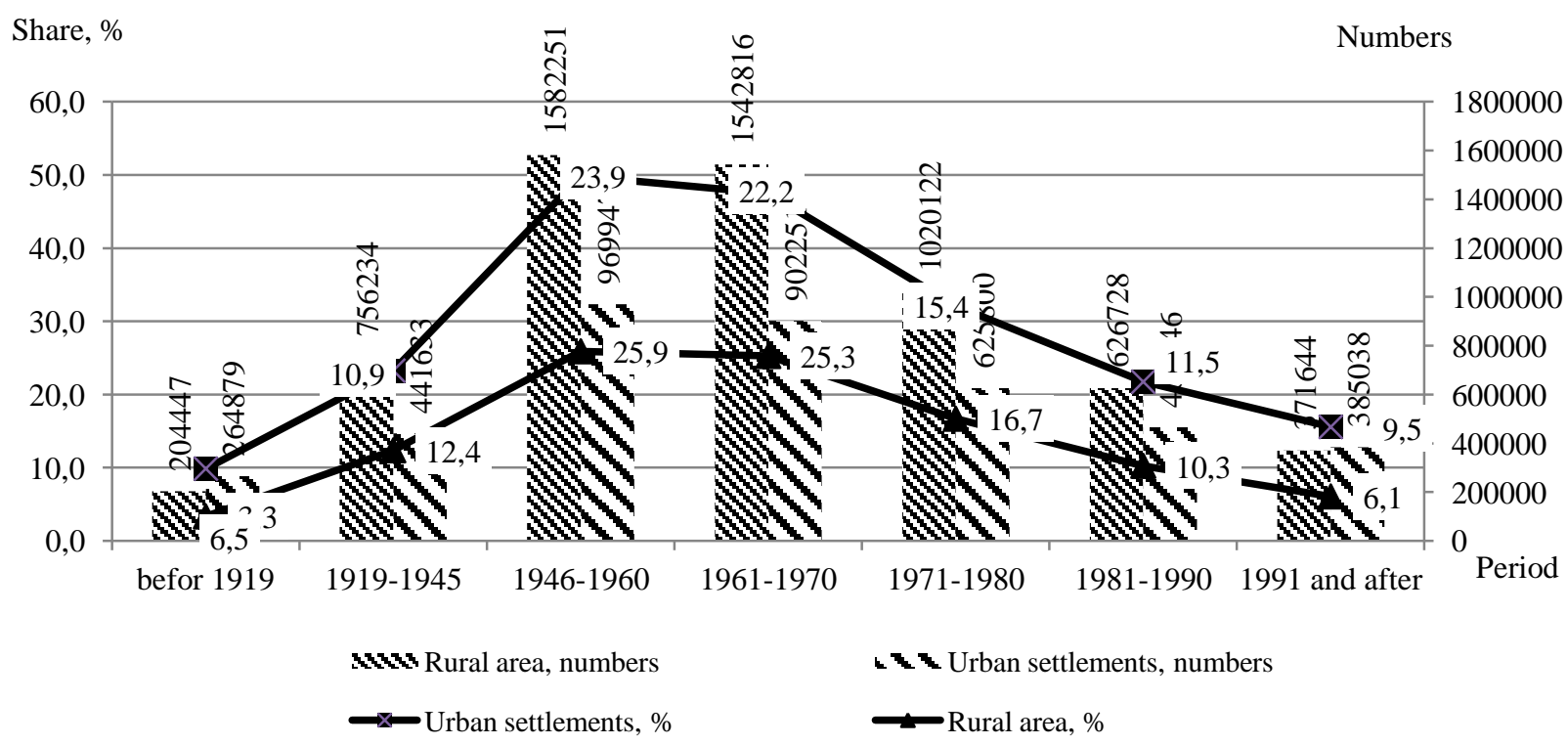

Fig. 3. The quantity and structure of the Ukrainian housing by years of construction Source: summarized by the authors on based [22, 23].

According to experts of the Ministry of Regional Development, Construction and Housing and Communal Services of Ukraine, more than $70 \%$ of the housing has been need thermomodernization. In Ukraine, first of all, a 1971s-1980s building has been needed

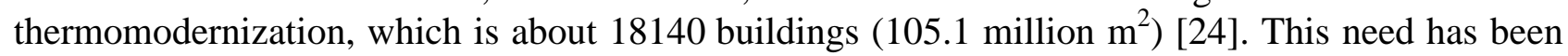
driven by the high level of buildings energy losses that were inherent in the construction technology used in the 1950s-1980s. Most of the heat is lost through the walls and the roof. 
Such buildings and structures consume between 160 and $240 \mathrm{~kW} / \mathrm{m}^{2}$ per year. The housing built between the mid-1980s and the early 2000s consumes more than $140 \mathrm{~kW} / \mathrm{m}^{2}$ annually. And only homes built later consume about $100 \mathrm{~kW} / \mathrm{m}^{2}$ per year, which meets current standards to date. These data has been indicated that the energy saving potential of the Ukrainian housing has been quite significant, which indicates the need for energy-saving reconstruction. The innovations developed in the construction sphere have been got the opportunity to build housing from $50 \mathrm{~kW} /$ $\mathrm{m}^{2}$ per year up to the so-called zero energy consumption in current conditions. The experience of buildings renovation in Germany over the last 20 years has been shown that in consequence of the complex rehabilitation of buildings with the thermal modernization measures implementation up to $50 \%$ of energy for heating and hot water can be saved. At the same time, the demand for primary energy has been on average reduced by 0.5-0.7 tonnes of conditional fuel per household per year. This means that greenhouse gas emissions will be less on average of 1.0-1.4 tonnes per household per year.

Estimation of urban and rural development periods has been shown that construction has been carried out almost simultaneously. During the years 1946-1960, over 1.5 million houses (23.9\%) have been erected in the countryside, approximately as many houses have been built in the countryside during the years 1961-1970. At that time, in the city settlements, it has been built 9 million homes, which is $51.2 \%$ of all city buildings. The share of new buildings in the countryside has been $9.5 \%$, in the city this indicator has been $6.1 \%$ (Table 2).

Table 2

Quantity and proportion of Ukrainian rural housing by years of building by region

\begin{tabular}{|c|c|c|c|c|c|c|c|c|c|c|}
\hline \multirow{3}{*}{$\begin{array}{l}\text { Regions of } \\
\text { Ukraine }\end{array}$} & \multirow{3}{*}{$\begin{array}{c}\text { Total } \\
\text { homes } \\
\text { quantity }\end{array}$} & \multicolumn{9}{|c|}{ including built in the period: } \\
\hline & & \multirow{2}{*}{$\begin{array}{l}\text { before } \\
1919 \mathrm{p} .\end{array}$} & \multirow{2}{*}{$\begin{array}{l}1919- \\
1945\end{array}$} & \multirow{2}{*}{$\begin{array}{c}1946- \\
1960\end{array}$} & \multirow{2}{*}{$\begin{array}{c}1961- \\
1970\end{array}$} & \multirow{2}{*}{$\begin{array}{c}1971- \\
1980\end{array}$} & \multicolumn{2}{|c|}{$1981-1990$} & \multicolumn{2}{|c|}{1991 and after } \\
\hline & & & & & & & quantity & share, \% & quantity & share, \% \\
\hline Ukraine & 6104242 & 204447 & 756234 & 1582251 & 1542816 & 1020122 & 626728 & 100,0 & 371644 & 100,0 \\
\hline \begin{tabular}{|l|} 
AR Crimia \\
\end{tabular} & 207140 & 3670 & 16060 & 47687 & 64478 & 39592 & 22707 & 3,6 & 12946 & 3,5 \\
\hline Vinnytsia & \begin{tabular}{|l|}
439186 \\
\end{tabular} & 22422 & 63134 & 121266 & 111745 & 64660 & 33557 & 5,4 & 22402 & 6,0 \\
\hline Volyn & 177504 & 1647 & 15890 & 48614 & 43940 & 3940 & 2822 & 0,5 & 936 & 0,3 \\
\hline Dnepropetrovsk & \begin{tabular}{|l|}
250082 \\
\end{tabular} & 13651 & 39145 & 67106 & 58687 & 34836 & 22343 & 3,6 & 14314 & 3,9 \\
\hline Donetsk & 189101 & 5078 & 18817 & 52955 & 50498 & 34810 & 18803 & 3,0 & 8140 & 2,2 \\
\hline Zhytomyr & 268898 & 7747 & 37237 & 74173 & 69155 & 41998 & 23811 & 3,8 & 14777 & 4,0 \\
\hline Zakarpatia & 231182 & 3521 & 22112 & 47790 & 50339 & 44978 & 35395 & 5,6 & 27047 & 7,3 \\
\hline Zaporozhye & 182936 & 10267 & 29187 & 44997 & 43129 & 29015 & 18825 & 3,0 & 7516 & 2,0 \\
\hline Ivano-Frankivsk & 272584 & 8503 & 35234 & 56842 & 59208 & 52412 & 36953 & 5,9 & 23432 & 6,3 \\
\hline Kiev & 377025 & 8168 & 40016 & 93991 & 90393 & 57927 & 46261 & 7,4 & 40269 & 10,8 \\
\hline Kirovohrad & 188004 & 10741 & 31606 & 51349 & 44130 & 27304 & 15316 & 2,4 & 7558 & 2,0 \\
\hline Lugansk & 140091 & 4856 & 14500 & 40009 & 38742 & 23098 & 13193 & 2,1 & 5693 & 1,5 \\
\hline Lviv & 343298 & 12331 & 53124 & 77443 & 78871 & 58959 & 37821 & 6,0 & 24749 & 6,7 \\
\hline Mykolaiv & \begin{tabular}{|l|}
153556 \\
\end{tabular} & 7031 & 20534 & 46512 & 36167 & 23149 & 14755 & 2,4 & 5408 & 1,5 \\
\hline Odessa & \begin{tabular}{|l|}
313557 \\
\end{tabular} & 22730 & 51022 & 80590 & 69440 & 46177 & 25756 & 4,1 & 17842 & 4,8 \\
\hline Poltava & 291265 & 9283 & 37860 & 82053 & 70891 & 42426 & 32120 & 5,1 & 16632 & 4,5 \\
\hline Rivne & \begin{tabular}{|l|}
204185 \\
\end{tabular} & 2705 & 22677 & 49150 & 46504 & 38501 & 25707 & 4,1 & 18941 & 5,1 \\
\hline Sumy & 192961 & 4467 & 23177 & 52488 & 56399 & 30623 & 18214 & 2,9 & 7593 & 2,0 \\
\hline Ternopilska & 228773 & 6910 & 32328 & 49851 & 63371 & 43732 & 22006 & 3,5 & 10575 & 2,8 \\
\hline Kharkiv & 233787 & 4330 & 18895 & 64101 & 64738 & 43438 & 25480 & 4,1 & 12805 & 3,4 \\
\hline Kherson & \begin{tabular}{|l|}
152088 \\
\end{tabular} & 4331 & 12292 & 34736 & 38803 & 35665 & 18481 & 2,9 & 7780 & 2,1 \\
\hline Khmelnytsky & \begin{tabular}{|l|}
294113 \\
\end{tabular} & 9383 & 35609 & 81351 & 86113 & 48003 & 22320 & 3,6 & 11334 & 3,0 \\
\hline \begin{tabular}{|l|} 
Cherkasy \\
\end{tabular} & \begin{tabular}{|l|}
305214 \\
\end{tabular} & 6820 & 29718 & 89936 & 82038 & 51749 & 30419 & 4,9 & 14534 & 3,9 \\
\hline Chernihiv & 195834 & 9600 & 27107 & 38823 & 41725 & 34452 & 26196 & 4,2 & 17931 & 4,8 \\
\hline Chernivtsi & 266225 & 4198 & 28625 & 86829 & 81501 & 38890 & 18635 & 3,0 & 7547 & 2,0 \\
\hline
\end{tabular}

Source: summarized by the authors on based [22, 24].

Analysis of indicators by Ukrainian regions has been shown that in the postwar period (19461960), 121266 houses have been built in rural areas in Vinnytsia region, in the following period (1961-1970), 111745 houses have been built in this region. It has been amounted total $53 \%$. The Chernihiv region also has been undergone large-scale reconstruction in the postwar period. It has been built more than 80,000 homes in each of these periods, accounting for $63.2 \%$ of the total 
buildings quantity of all periods. Khmelnitsky and Cherkasy regions has been shown similar trends, with the building quantity over 80,000 houses in each period and a total share of more than $56 \%$. The lowest quantity of rural houses have been built during the years 1945-1960 in Volyn region, which as a whole has the smallest quantity of houses built in all time.

Regarding new buildings in rural areas, ie houses built after 1991, so most of them have been built in Kyiv region (40269 houses, or $10.8 \%$ of the total quantity of new buildings in Ukraine), Zakarpatia region (27047 houses, or $7.3 \%$ ) and Vinnytsia region (22402 homes, or $6 \%)$. The lowest quantity of new rural houses has been built in Lugansk (5693 houses, or $1.5 \%$ ), Sumy and Chernihiv regions, it is about 7.5 thousand houses ( $2 \%$ each region). In the $80-90 \mathrm{~s}$, the largest quantity of rural houses has been built in Lviv region; it is 37821 houses (6\% of the total quantity of houses in this period in Ukraine).

In the context of the justification of the National Energy Efficiency Action Plan for the period up to 2020, the energy saving potential in the housing has been identified at the state level. The document [25] states that Ukraine has not been collected official statistics on the energy consumption of different types of buildings in different climatic zones. Therefore, the energy efficiency potential has been determined on the basis of computer simulation of energy consumption according to the methodology. The computer models have been based on the real thermal characteristics of the buildings, their age, type and features of the four climatic zones of Ukraine, which as a result has been extrapolated to the total housing. The following standard homes have been accepted as calculating agents:

- house of cottage type for one family with a total area of $60 \mathrm{~m}^{2}$;

- 2-storey house with 2 entrances;

- 5-storey building with 4 entrances;

- 10-storey building on one entrance;

- 5-storey single-storey dormitory building [25].

These types of buildings have been the most typical for modern Ukraine. By rural areas, single family cottage-type houses have been occupied the highest proportion, 2-storey house with 2 entrances (or two- or four-owner houses) and dormitory have been also typical, multistoreyed houses have been not typical for rural areas.

The results of calculations of energy consumption characterize the data in Table. 3.

Table 3

Energy consumption of existing houses, determined by the results of modeling in terms of climatic zones of Ukraine, tonnes of oil equivalent (toe)

\begin{tabular}{|c|c|c|c|c|c|c|c|c|}
\hline \multirow{2}{*}{$\begin{array}{l}\text { Necessary } \\
\text { energy, toe }\end{array}$} & \multicolumn{2}{|c|}{ Zone I } & \multicolumn{2}{|l|}{ Zone II } & \multicolumn{2}{|c|}{ Zone III } & \multicolumn{2}{|l|}{ Zone IV } \\
\hline & $\begin{array}{c}\text { volume of } \\
\text { consumption, toe }\end{array}$ & $\begin{array}{l}\text { share, } \\
\%\end{array}$ & $\begin{array}{c}\text { volume of } \\
\text { consumption, } \\
\text { toe }\end{array}$ & $\begin{array}{c}\text { share, } \\
\%\end{array}$ & $\begin{array}{c}\text { volume of } \\
\text { consumption, } \\
\text { toe }\end{array}$ & $\begin{array}{l}\text { share, } \\
\%\end{array}$ & $\begin{array}{c}\text { volume of } \\
\text { consumption, toe }\end{array}$ & $\begin{array}{l}\text { share, } \\
\%\end{array}$ \\
\hline $\begin{array}{l}\text { Zone's } \\
\text { characteristics }\end{array}$ & \multicolumn{2}{|c|}{ above 3501 degrees-day } & \multicolumn{2}{|c|}{ 3001-3500 degrees-day } & \multicolumn{2}{|c|}{ 2501-3000 degrees-day } & \multicolumn{2}{|c|}{ less than 2500 degrees-day } \\
\hline $\begin{array}{l}\text { Regions } \\
\text { belonging to the } \\
\text { zone }\end{array}$ & \multicolumn{2}{|c|}{$\begin{array}{c}\text { Ternopil, Rivne, Zhytomyr, } \\
\text { Khmelnytsky, Vinnytsia, Kyiv, } \\
\text { Cherkasy, Chernihiv, Poltava, } \\
\text { Sumy, Kharkiv, Lugansk, } \\
\text { Donetsk, Kirovograd }\end{array}$} & \multicolumn{2}{|c|}{$\begin{array}{c}\text { Dnepropetrovsk, } \\
\text { Zaporizhia, Volyn, } \\
\text { Lviv, Ivano-Frankivsk, } \\
\text { Chernivtsi }\end{array}$} & \multicolumn{2}{|c|}{$\begin{array}{l}\text { Odessa, Mykolaiv, } \\
\text { Kherson, Zakarpatia }\end{array}$} & \multicolumn{2}{|c|}{ AR Crimia } \\
\hline $\begin{array}{l}\text { Houses up to } 6 \\
\text { floors in height }\end{array}$ & 1660022 & 10.1 & 561611 & 10.1 & 239408 & 7.7 & 40723 & 9.6 \\
\hline $\begin{array}{l}\text { Houses with } 5 \\
\text { storey }\end{array}$ & 2154469 & 13.1 & 766560 & 13.7 & 397414 & 12.8 & 136109 & 32.2 \\
\hline $\begin{array}{l}\text { Houses with a } 2 \\
\text { to } 4 \text { storey }\end{array}$ & 1431042 & 8.7 & 404753 & 7.3 & 237487 & 7.6 & 29731 & 7.0 \\
\hline Dormitories & 221404 & 1.3 & 81205 & 1.5 & 41762 & 1.3 & 7177 & 1.7 \\
\hline Cottages & 11016089 & 66.8 & 3766048 & 67.5 & 2197323 & 70.6 & 209072 & 49.4 \\
\hline $\begin{array}{l}\text { Annual houses } \\
\text { energy } \\
\text { consumption }\end{array}$ & 16483026 & 100.0 & 5580177 & 100.0 & 3113394 & 100.0 & 422812 & 100.0 \\
\hline Total & & & & 2559 & & & & \\
\hline
\end{tabular}

Source: summarized by the authors on based [25]. 
For calculating the energy consumption indicators in typical houses, the Ukrainian climate zones have been also taken into account. The basis of zoning has been the degree-day index of the heating period (GDOP). It is calculated as the multiplication of the difference between the indoor air temperature and the average outside air temperature and the duration of the heating period. That is, if this indicator is lower, the less energy will be consumed in the houses.

Experimental data has been shown that the received energy consumption of the houses sector has been 25 million tonnes. Specific energy consumption, that is, the average energy productivity in Ukraine is $276 \mathrm{kWh} / \mathrm{m}^{2}$ of energy consumed and varies from 145 to $327 \mathrm{kWh} / \mathrm{m}^{2}$ depending on the type of building and the climate zone in which the building is located. An important factor in the houses energy efficiency is the equipment of houses with sources of heating, water supply, cooking. The peculiarities of the rural houses have been the absence of central heat and water supply, as well as the predominance of natural gas as a heating source (Table 4).

The proportion of the equipped total living space in rural areas, 2014, 2018, \%

\begin{tabular}{|c|c|c|c|c|c|c|c|c|c|c|c|c|c|c|c|c|}
\hline \multirow{3}{*}{$\begin{array}{l}\text { Regions of } \\
\text { Ukraine }\end{array}$} & \multirow{2}{*}{\multicolumn{2}{|c|}{$\begin{array}{l}\text { water } \\
\text { supply }\end{array}$}} & \multirow{2}{*}{\multicolumn{2}{|c|}{$\begin{array}{l}\text { hot water } \\
\text { supply }\end{array}$}} & \multirow{2}{*}{\multicolumn{2}{|c|}{ sewage system }} & \multicolumn{6}{|c|}{ heating } & \multicolumn{4}{|c|}{ gas } \\
\hline & & & & & & & \multicolumn{2}{|c|}{$\begin{array}{c}\text { the central } \\
\text { one }\end{array}$} & \multicolumn{2}{|c|}{$\begin{array}{c}\text { from } \\
\text { individual } \\
\text { installations }\end{array}$} & \multicolumn{2}{|c|}{ oven } & \multicolumn{2}{|c|}{ natural } & \multicolumn{2}{|c|}{ liquefied } \\
\hline & 2014 & 2018 & 2014 & 2018 & 2014 & 2018 & 2014 & 2018 & 2014 & 2018 & 2014 & 2018 & 2014 & 2018 & 2014 & 2018 \\
\hline Ukraine & 28,9 & 37,4 & 16,9 & 24,4 & 25,2 & 33,8 & 1,0 & 1,4 & 48,1 & 54,0 & 44,2 & 39,5 & 53,2 & 57,5 & 31,0 & 26,8 \\
\hline Vinnytsia & 17,1 & 23,2 & 9,3 & 12,4 & 14,8 & 20,0 & 0,6 & 2,0 & 37,0 & 40,3 & 49,8 & 46,2 & 41,6 & 45,0 & 39,6 & 37,2 \\
\hline Volyn & 33,1 & 44,5 & 23,4 & 35,6 & 30,2 & 41,7 & 0,0 & 0,1 & 39,9 & 48,6 & 60,1 & 51,3 & 43,5 & 50,2 & 32,3 & 26,7 \\
\hline $\begin{array}{l}\text { Dnipro- } \\
\text { petrovsk }\end{array}$ & 35,5 & 39,2 & 11,7 & 13,5 & 25,0 & 28,8 & 0,9 & 2,0 & 59,6 & 66,1 & 28,7 & 28,2 & 63,5 & 66,5 & 24,0 & 21,9 \\
\hline Donetsk & 37,7 & 39,6 & 5,8 & 6,8 & 24,6 & 28,1 & 2,1 & 1,8 & 19,5 & 24,0 & 59,7 & 54,9 & 24,8 & 26,7 & 26,7 & 23,7 \\
\hline Zhytomyr & 11,8 & 15,8 & 8,2 & 11,5 & 11,6 & 15,7 & 0,1 & 0,5 & 36,0 & 40,6 & 63,6 & 58,5 & 39,1 & 42,9 & 44,1 & 40,2 \\
\hline Zakarpatia & 68,3 & 73,6 & 60,9 & 65,7 & 67,3 & 73,6 & 0,1 & - & 65,0 & 69,2 & 34,5 & 30,1 & 62,4 & 66,1 & 19,4 & 17,8 \\
\hline Zaporozhye & 29,7 & 33,9 & 20,8 & 24,9 & 27,0 & 31,3 & 1,1 & 1,4 & 40,3 & 44,0 & 54,3 & 50,6 & 42,1 & 45,1 & 47,5 & 44,8 \\
\hline $\begin{array}{l}\text { Ivano- } \\
\text { Frankivsk }\end{array}$ & 23,3 & 39,6 & 18,2 & 35,3 & 22,8 & 39,2 & 1,5 & 0,4 & 56,4 & 65,9 & 38,7 & 30,6 & 74,1 & 74,5 & 9,8 & 8,5 \\
\hline Kiev & 36,6 & 50,2 & 26,5 & 36,7 & 34,7 & 48,5 & 1,9 & 4,1 & 82,0 & 83,2 & 15,3 & 10,6 & 83,5 & 86,9 & 13,6 & 9,9 \\
\hline Kirovohrad & 12,6 & 17,1 & 5,4 & 8,4 & 10,8 & 15,0 & 0,1 & - & 28,4 & 34,2 & 65,8 & 65,2 & 22,6 & 25,8 & 58,3 & 55,3 \\
\hline Lugansk & 28,2 & 32,6 & 9,4 & 12,0 & 25,6 & 31,0 & 0,2 & 0,6 & 40,2 & 56,7 & 18,2 & 22,6 & 64,6 & 68,4 & 10,0 & 8,3 \\
\hline Lviv & 32,4 & 47,8 & 24,0 & 39,7 & 30,6 & 47,0 & 0,6 & 0,8 & 38,4 & 49,4 & 54,7 & 49,8 & 71,1 & 76,3 & 12,1 & 9,5 \\
\hline Mykolaiv & 34,3 & 40,4 & 20,1 & 24,9 & 25,6 & 31,5 & 0,7 & - & 43,6 & 49,5 & 51,1 & 45,9 & 42,0 & 45,4 & 47,2 & 43,5 \\
\hline Odessa & 45,8 & 49,7 & 16,4 & 19,7 & 31,8 & 35,5 & 2,1 & 2,6 & 26,6 & 31,8 & 43,4 & 43,8 & 30,5 & 33,4 & 55,8 & 48,5 \\
\hline Poltava & 27 & 31,4 & 11,6 & 15,0 & 24,2 & 27,8 & 1,7 & 3,4 & 67,1 & 67,8 & 26,1 & 22,2 & 71,9 & 73,3 & 18,7 & 16,0 \\
\hline Rivne & 28,3 & 35,0 & 18,8 & 23,4 & 26,4 & 32,8 & 0,3 & 2,3 & 45,1 & 48,3 & 54,1 & 47,3 & 47,3 & 50,2 & 26,3 & 22,2 \\
\hline Sumy & 18,6 & 24,5 & 8,8 & 11,6 & 15,7 & 20,9 & 0,4 & 1,6 & 46,4 & 49,7 & 46,9 & 43,6 & 43,2 & 46,9 & 32,3 & 30,1 \\
\hline Ternopilska & 30,7 & 39,1 & 18,0 & 25,2 & 24,3 & 32,2 & 0,7 & 0,1 & 66,0 & 71,4 & 31,1 & 26,4 & 75,1 & 77,3 & 16,3 & 13,0 \\
\hline Kharkiv & 26,9 & 31,8 & 11,5 & 13,3 & 24,4 & 29,2 & 5,3 & 4,0 & 51,2 & 55,8 & 38,6 & 33,5 & 56,2 & 60,3 & 29,7 & 25,4 \\
\hline Kherson & 45,3 & 48,9 & 12,5 & 15,5 & 32,7 & 34,9 & 0,8 & 0,2 & 31,6 & 34,3 & 52,2 & 51,4 & 28,6 & 31,5 & 66,3 & 61,7 \\
\hline Khmelnytsky & 12,6 & 19,3 & 7,4 & 13,6 & 12,1 & 18,1 & 0,1 & 0,1 & 53,4 & 58,1 & 44,0 & 40,4 & 57,6 & 59,8 & 31,8 & 29,0 \\
\hline Cherkasy & 25,8 & 31,6 & 14,6 & 19,6 & 24,4 & 30,0 & 0,5 & 0,3 & 50,8 & 56,4 & 43,2 & 38,8 & 48,6 & 52,9 & 34,9 & 31,5 \\
\hline Chernivtsi & 29,4 & 39,8 & 26,6 & 37,2 & 28,9 & 39,5 & - & 0,0 & 46,6 & 52,1 & 52,2 & 44,1 & 54,4 & 56,9 & 33,0 & 29,9 \\
\hline Chernihiv & 16,7 & 22,2 & 8,9 & 12,1 & 14,5 & 19,6 & 0,4 & 0,9 & 39,0 & 43,3 & 60,5 & 55,8 & 36,1 & 39,6 & 37,4 & 33,9 \\
\hline
\end{tabular}

Source: summarized by the authors on based [16, 20].

A positive tendency for the provision of rural houses with the main types of communal systems has been observed during 2014-2018. Thus, in Ukraine as a whole, the proportion of homes with water supply has been increased from $28.9 \%$ to $37.4 \%$, with hot water supply has been increased from $16.9 \%$ to $24.4 \%$, and sewage has been increased from $25.2 \%$ to $33,8 \%$. Despite the tendency to increase the availability of these types of communal systems, a lot of homes do not have water, sewage and hot water. Regarding heating, the share of houses equipped with centralized heating remains insignificant $(1.4 \%)$. The rural houses share with gas boilers have been increased 
from $48.1 \%$ to $54 \%$, and the rural houses share with furnace heating has been decreased accordingly from $44.2 \%$ to $39.5 \%$ in 2018 compared to 2014 .

Speaking about gas for cooking, share of homes using natural gas has been increased from $53.2 \%$ to $57.5 \%$ in 2018 compared to 2014. Most rural houses with district heating have been located in Kyiv (4,1\%), Poltava (3.4\%) and Kharkiv (4\%) regions, gas boilers have been in Kyiv (83.2\%), Ternopil (71.4\%), Zakarpatia (69.2\%), Poltava (67.8\%), Dnipropetrovsk (66.1\%), Ivano-Frankivsk $(65.9 \%)$. The most significant increase in the share of houses equipped with gas boilers in 2018 compared to 2014 has been observed in these regions. Furnace heating has been most popular in Kirovograd (65.2\% of houses have a furnace), Zhytomyr $(58.5 \%)$ and Chernihiv regions $(55.8 \%)$ (Fig. 2).

Share, $\%$

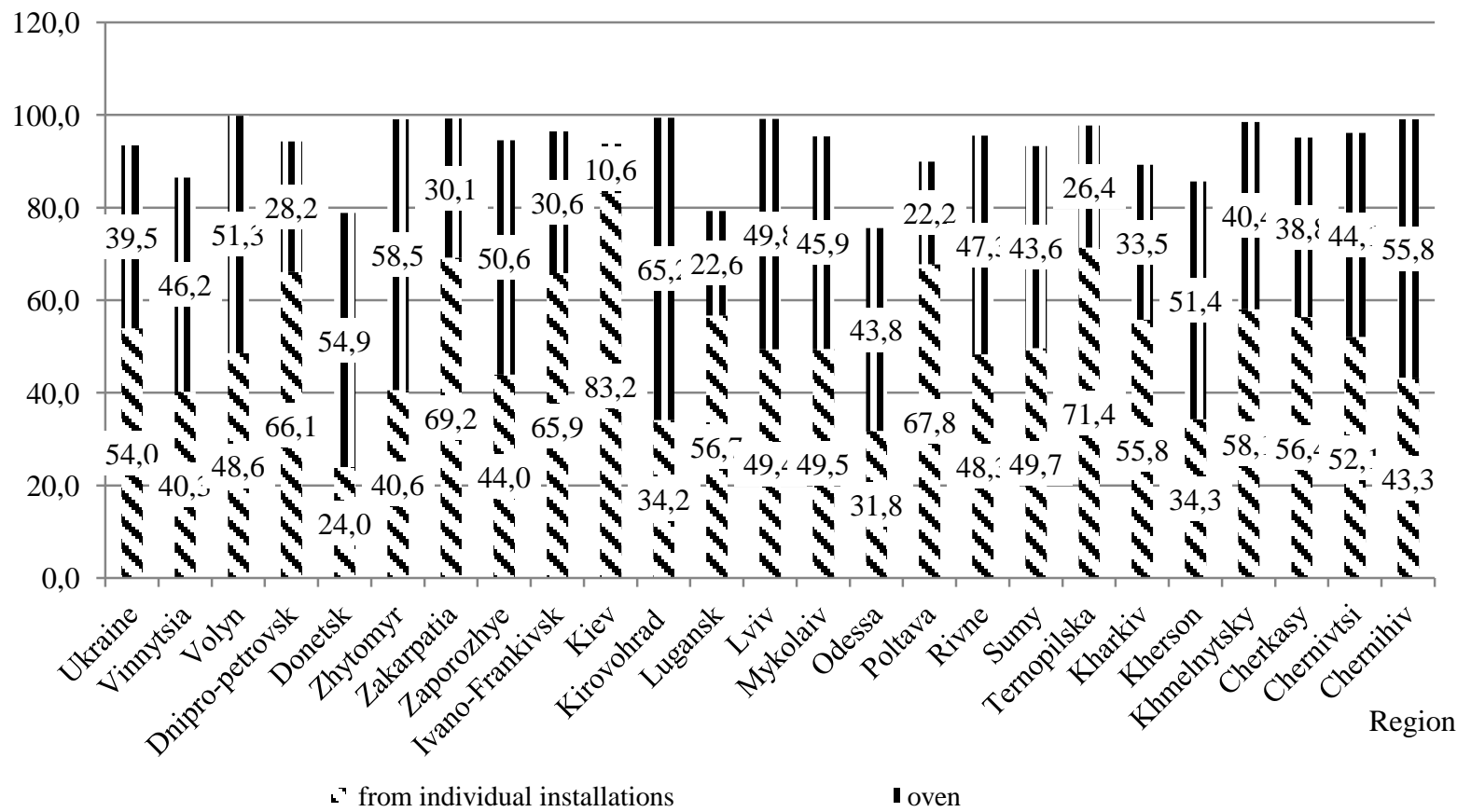

Fig. 2. The structure of rural houses, depending on their equipment with the appropriate type of heating, \%

Source: summarized by the authors on based [16].

The acute crisis of the entire economic system of Ukraine in 2014-2018 has been caused the construction industry. Housing building by new energy efficiency standards has not been carried out. The cost of such housing is too expensive, which makes it impossible to meet the needs of most Ukrainians in modern, high-quality, economical housing.

Studies have been shown that energy costs for heating homes in the city and rural areas have been significantly different. Thus, on average in the city in an apartment building for heating per $1 \mathrm{~m}^{2}$ of living space for the heating season (6 months) $0.1 \mathrm{Gcal}$ has been spent. The average tariff per $1 \mathrm{Gcal}$ in Ukraine has been $1400 \mathrm{UAH}$ (however, there are significant differences in the regions of Ukraine). The highest prices for heating have been in Kyiv and Rivne regions, the lowest prices have been in Odessa, Chernivtsi, Lviv, and Zaporozhye.

So, the average cost of heating $1 \mathrm{~m}^{2}$ of living space for the heating season in the city with centralized heating has been $140 \mathrm{UAH}$. If the heating in the city has been carried out with the help of individual gas boilers, the cost has been about $100 \mathrm{UAH} / \mathrm{m}^{2}$. In rural areas, the cost of heating has been significantly higher than in the city. Most rural homes use individual gas boilers. Some households have been combined gas heating with furnace, solid fuel or other (alternative) type of 
heating. In the case of gas heating, the average cost of gas per $1 \mathrm{~m}^{2}$ of living space in rural areas for the heating season has been $320 \mathrm{UAH}$. Thus, the average cost of heating for the whole period of an average rural house has been $20000 \mathrm{UAH}$ (Table 5).

Table 5

The houses heating costs during the heating season in the city and rural areas of Ukraine, 2018

\begin{tabular}{|c|c|c|c|c|}
\hline \multirow[b]{2}{*}{ Indicators } & \multicolumn{4}{|c|}{ Types of heating } \\
\hline & $\begin{array}{c}\text { the central } \\
\text { one }\end{array}$ & \begin{tabular}{|c|} 
from individual \\
installations (gas \\
boilers)
\end{tabular} & oven & total \\
\hline \multicolumn{5}{|c|}{ Rural areas } \\
\hline Cost of heating per season (6 months) per $1 \mathrm{~m}^{2}$ & 140 & 320 & 130 & - \\
\hline Total rural housing, $\mathrm{m}^{2}$ & 387757332 & & & 387757332 \\
\hline $\begin{array}{l}\text { The coefficient of equipment with the appropriate type of } \\
\text { heating }\end{array}$ & 1.4 & 54 & 39.5 & 94.9 \\
\hline Total rural housing, with appropriate heating type, $\mathrm{m}^{2}$ & 5428603 & 209388959 & 153164146 & 367981708,1 \\
\hline Heating costs for the heating season, UAH million & 760.0 & 67004.5 & 19911.3 & 87675.8 \\
\hline $\begin{array}{l}\text { Average cost of heating for the season (6 months) per } 1 \mathrm{~m}^{2} \text {, } \\
\text { UAH }\end{array}$ & - & - & - & 238.26 \\
\hline $\begin{array}{l}\text { Probable heating costs provided only furnace heating, UAH } \\
\text { million }\end{array}$ & - & - & - & 47837.6 \\
\hline Savings due to substitution of heating type, UAH million & - & - & - & 39838.2 \\
\hline Savings due to substitution of heating type, $\%$ & - & - & - & 45.4 \\
\hline \multicolumn{5}{|c|}{ Urban settlement } \\
\hline Cost of heating per season (6 months) per $1 \mathrm{~m}^{2}$ & 140 & 100 & 130 & - \\
\hline Total rural housing, $\mathrm{m}^{2}$ & 590044799 & - & - & 387757332 \\
\hline $\begin{array}{l}\text { The coefficient of equipment with the appropriate type of } \\
\text { heating }\end{array}$ & 72,8 & 5,6 & 0,7 & 79,1 \\
\hline Total rural housing, with appropriate heating type, $\mathrm{m}^{2}$ & 429552614 & 33042509 & 4130314 & 466725436 \\
\hline Heating costs for the heating season, UAH million & 60137.4 & 3304.3 & 536.9 & 63978.6 \\
\hline $\begin{array}{l}\text { Average cost of heating for the season (6 months) per } 1 \mathrm{~m}^{2} \text {, } \\
\text { UAH }\end{array}$ & - & - & - & 137.08 \\
\hline
\end{tabular}

Source: calculated by the authors .

In total, 87675.8 million UAH has been spent in the Ukrainian rural territories during the season for heating, and UAH 63978.6 million has been spent in the city. On average, considering the share of each type of heating in the city and in the countryside, it has been estimated that the cost of heating $1 \mathrm{~m}^{2}$ in the rural areas has been $238.26 \mathrm{UAH}$, in the city has been 137.08 UAH. Assuming that all heating in the rural housing would be stove, which mainly works based on firewood, then savings of UAH 39838.2 million, or $45.4 \%$ would be achieved. Of course, this is not a strategic proposal for energy conservation; because furnace heating is not modern and has several disadvantages. However, this calculation has been shown the efficiency of alternative fuel use. Currently, a mechanism to encourage the installation of solid fuel boilers has been developed in Ukrainian houses, in particular by offsetting their cost when issuing appropriate loans. Solid fuel boilers can be targeted at a wide range of consumption, from domestic to industrial use. Solid fuel boilers have several advantages over other types of boilers: affordability, autonomy and cheap fuel, as well as the fact that the choice of fuel depends on the owner. The assortment of solid fuel boilers is very high, and the fuel for them (such as coal) at relatively low cost has a huge thermal effect [26]. Solid fuel boilers have been conditionally classified according to the following characteristics (Table 6).

Approximately $54 \%$ of the rural population has been used natural gas for heating, so its rise in price since 2014 has been very negative for Ukrainians. A household with square $65 \mathrm{~m}^{2}$, using automatic boilers, have been needed about 300-350m3 of gas per month per the heating season. At the current price it has been more than 2.5 thousand UAH per month. This has been more than $30 \%$ of the average salary in rural areas and sometimes more than the monthly pension. Thus, combining gas heating with an alternative, such as equipping the premises with a heat-fuel boiler, has been economically feasible and energy-efficient. 
Classification feature of solid fuel boilers

\begin{tabular}{|l|l|}
\hline $\begin{array}{l}\text { Classification } \\
\text { feature }\end{array}$ & \multicolumn{1}{c|}{ Characteristic } \\
\hline $\begin{array}{l}\text { Depending on } \\
\text { the type of } \\
\text { fuel used }\end{array}$ & $\begin{array}{l}\text { - firewood boilers: dry wood is the main fuel for these boilers; } \\
\text { - coal boilers: they are still called "omnivorous". In such boilers large pieces of solid fuel have } \\
\text { been burned, such as coal and lignite, peat and coal braces, anthracite, as well as wood and some sort } \\
\text { of construction debris; } \\
\text { - pellet boilers: fuel pellets have been used as fuel for these boilers; } \\
\text { - mixed fuel boilers - several types of fuel: coal, wood, pellets, eco-peas, oats, etc. could be } \\
\text { burned here. }\end{array}$ \\
\hline $\begin{array}{l}\text { Depending on } \\
\text { the method of } \\
\text { combustion of } \\
\text { the fuel }\end{array}$ & $\begin{array}{c}\text { - naturally aspirated boilers - in these models, the combustion process has been controlled by a } \\
\text { thentatic traction regulator without additional forced air supply; }\end{array}$ \\
& $\begin{array}{l}\text { additional fan, which additionally adds air to the furnace, and the fan power has been regulated } \\
\text { depending on the combusted fuel and smoke draft; } \\
\text { - pyrolysis boilers: it is boilers with a more complex combustion mechanism, which consists in } \\
\text { the fact that the firewood in the primary chamber has been burned in a low oxygen environment and } \\
\text { thus the combustible gas is released, which is ignited in the secondary chamber; } \\
- \text { long-burning boilers: in these boilers the combustion process takes place from top to bottom, } \\
\text { whereby a longer and even heating of the coolant has been achieved on one tab of the fuel. }\end{array}$ \\
\hline
\end{tabular}

Source: developed by the authors .

In addition, the State Agency for Energy Efficiency and Energy Conservation of Ukraine has been calculated the economic effect of the housing modernization (Table 7). The results of the calculations has been shown that the implementation of these energy-efficient measures in the existing Ukrainian houses and improvement of their energy efficiency will provide to a reduction of total energy consumption by 15.3 million tonnes, or $60 \%$.

Table 7

Energy saving potential in the housing sector

\begin{tabular}{|l|c|c|c|}
\hline \multirow{2}{*}{ Measures } & \multicolumn{3}{c|}{ Potential, thousand toe } \\
\cline { 2 - 4 } & Apartment buildings & Cottages & Total \\
\hline Additional wall insulation & 1699 & 3313 & 5012 \\
\hline Installation of energy efficient windows & 975 & 1901 & 2876 \\
\hline Additional roof insulation & 928 & 1809 & 2736 \\
\hline Installation of energy efficient engineering equipment & 1439 & 2806 & 4245 \\
\hline Replacement of interior lighting & 149 & 291 & 440 \\
\hline Total & 5190 & 10120 & 15310 \\
\hline
\end{tabular}

Source: [25].

Therefore, the energy savings potential in the housing sector, particularly in rural areas, has been significant. The rural houses have been needed to implement measures to reduce heat consumption. Housing and utility companies have been consumed about 10 billion $\mathrm{kWh}$ each year of electricity and 8.5 billion $\mathrm{m}^{3}$ of natural gas. With a steady decline in population, energy consumption per Ukrainian citizen in the household sector have been not decreased, and in some regions even increases. This condition has been explained by the following reasons:

1. Energy consumption of household appliances, machines and mechanisms has been increased.

2. Energy savings in the housing sector have not yet gained a critical mass, which would have a significant impact on reducing their consumption.

3. Today, about $40 \%$ of the state's energy resources have been used for houses heating, $2 / 3$ of them have been simply lost during transportation and due to the high energy intensity of buildings

4. Energy, gas and water production and distribution companies have not been very active in introducing resource-saving innovations. Quantity of low-waste and resource-saving technologies has been ranged from 6 to 50 per year, with total innovations over the 10 to 163 year [13].

The level of energy consumption for housing heating has been remained at the level of 1980s design decisions (an average of $210-240 \mathrm{kWh} / \mathrm{m}^{2}$ per year). This is at times worse than in European countries (around 100) [27]. 
Developed countries, first and foremost, EU countries that have already made significant strides in addressing the buildings energy efficiency, have been minimized their heat and electricity needs, continue to look for new sources of energy and develop energy-saving measures. For example, by 2020, European countries plan to completely switch to the construction of passive (zero energy) and energy-autonomous (which provide more energy than they consume) homes. Such homes have an independent grid that does not require the cost of maintaining a comfortable temperature. The house has been heated by alternative renewable energy sources (solar collectors, heat pumps, wind turbines, etc.), as well as taking into account the heat generated by people living in it, household appliances, etc. At the same time, heat losses are prevented due to the design features of the building, which uses modern energy-saving technologies and high-efficiency thermal insulation materials for construction [28, 29] (Table 8).

Table 8

\section{Heat losing depending on the type of buildings in the example of Germany}

\begin{tabular}{|l|c|c|}
\hline \multicolumn{1}{|c|}{ The house has an area of $140 \mathrm{~m}^{2}$} & $\begin{array}{c}\text { Annual energy consumption, } \\
\mathrm{kWg} /\left(\mathrm{m}^{2} \text { year }\right)\end{array}$ & Specific heat loss, $\mathrm{Wg} / \mathrm{m}^{2}$ \\
\hline Old building & 300 & 136 \\
\hline The typical house of the 70's & 200 & 91 \\
\hline The typical house of the 80's & 150 & 68 \\
\hline House of low energy consumption of the 90's & to 70 & $7-14$ \\
\hline House of ultra-low power consumption & $15-30$ & less 7 \\
\hline Modern passive house & less 15 & \\
\hline
\end{tabular}

Source: summarized by the authors on based [28].

Energy management procedures, automatic adjustment, hydraulic balancing of the heating system, thermostatic radiator valves all have been contributed to energy efficiency. Reducing energy consumption also have been helped reduce environmental pollution from non-renewable energy sources (natural gas, fuel oil, coal), which has a positive effect on the environment both locally and globally.

The Directive on the Energy Performance of Buildings (EPBD) [29] has been established the energy efficiency class of a building from A, for energy consumption less than or equal to ( $25 \mathrm{kWh}$ / $\left(\mathrm{m}^{2}\right.$ year $)$, to $\mathrm{G}$, for consumption, exceeding $\left(450 \mathrm{kWh} / \mathrm{m}^{2}\right.$ year $)$. The following energy conservation goals have been declared in Germany:

- to reduce heat demand over $20 \%$ by 2020 ;

- increase the share of renewable energy sources in total consumption over $35 \%$ by 2020 (over $80 \%$ by 2050);

- to achieve a reduction of primary energy demand over $80 \%$ by 2050 and to fully transition to the construction of passive buildings [29, 30, 31].

The heating system modernization with the installation of solar thermal plants, heat pumps, biomass heating systems, wood (wood chips, pellets) have been allowed significantly increase energy efficiency. A significant reduction in heat loss could be achieved only by taking a comprehensive approach to the task at hand. In addition, a number of factors should be taken into account, such as overheating of the premises during the transitional period of the year, excessive heat losses due to the low efficiency of external pipelines insulation, excessive actual air exchange in the premises, losses of operational and organizational nature, as well as heat losses caused by unforeseen factors.

The diagnostics of the structure and condition of the housing sphere indicates the necessity of carrying out its complex energy efficient remediation. Renovation of a house is a complex carrying out of actions taking into account technical, economic, and social factors of a dwelling house in order to restore its original technical condition; achieving modern standards for its individual components and maximizing energy savings. Carrying out complex energy-saving renovation (or energy modernization) of the building allows: extend the life of the house; significantly reduce energy consumption; to reduce the owner's money for heating and electricity; significantly reduce greenhouse gas emissions; increase the market value of the housing; to provide comfortable and safe accommodation. The owners should take care to identify the causes of their occurrence and 
justify the most effective energy-efficient measures to overcome them, that is, to conduct a comprehensive energy audit. Energy audits should be performed by specially trained and experienced energy auditors. In general, the process of implementing energy-efficient renovation and energy audit of the house is shown in Fig. 3.

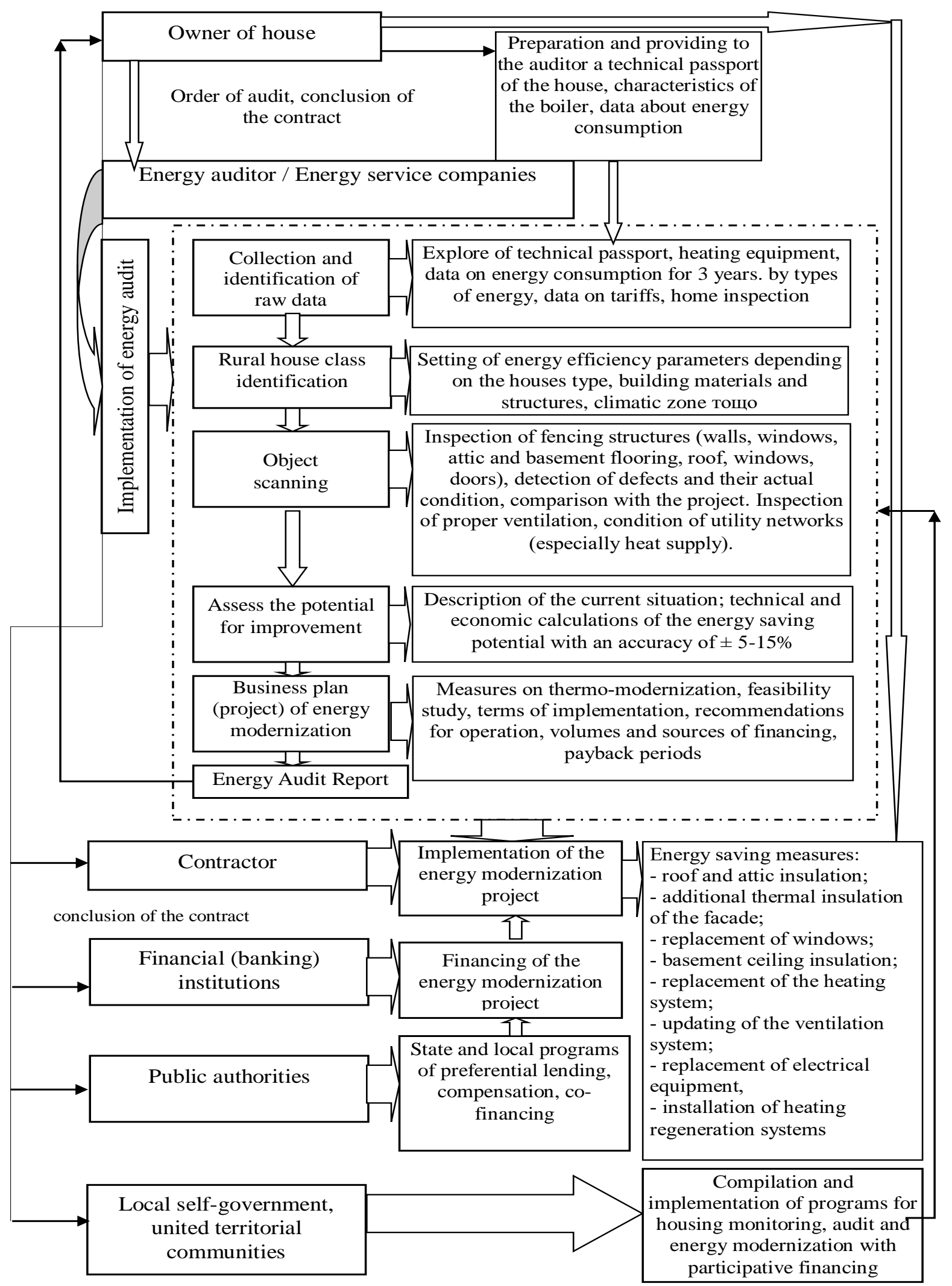

Fig. 3. Mechanism of rural housing energy-saving reconstruction

Source: developed by the authors . 
Energy audits include a survey of buildings, an assessment and analysis of the current situation and the various measures that can be taken to reduce energy consumption and improve the climate in the building. The results of the energy audit are provided in an appropriate report describing the recommended measures with the appropriate volumes and sources of investment, savings and profit of the owner.

In order to comprehensively address the energy losses issue in the housing sector, public authorities and local self-government should, in various ways, stimulate the citizens to conduct energy audits and implement energy-saving remedial measures in their own premises. For example, the introduction of a state-of-the-art program for energy-efficient renovation of buildings in Germany has been allowed the successful reconstruction of about $3 / 4$ of the total houses over 20 years. About $60 \%$ of energy has been saved in renovated homes. Complex renovation of old buildings has been $1 / 3$ of the cost of construction of new ones.

For the effective transformation of rural and urban houses with the creation of investmentattractive climate and the availability of affordable modern comfortable housing at the national and regional level, it has been necessary to provide the following measures:

- creation of a viable state program for investing in the construction and modernization of housing sector, in particular, in rural area;

- implementation of energy saving motivational measures;

- ensuring compliance with the requirements of modern building and energy standards;

- creation favorable financing conditions achieved through price stabilization policies and effective private and public lending instruments;

- ensuring social guarantees for the poor;

- ensuring training for personnel in the sphere of construction and reconstruction, planning, management and financing.

Conclusions. The current state of the Ukrainian housing, in particular in rural area, as well as the energy and economic situation in the country, have been required a solution to the problem of improving energy efficiency in the housing sector. In general, the experience of developed countries has been pointed to the need for state regulation of energy saving processes in the housing sector and providing a purposeful policy to increase the energy efficiency of houses.

Effective activity of the specialized energy efficiency fund to ensure stable financing of housing renovation projects should be the basis of the Ukrainian government's efforts to improve the energy efficiency of the housing sector, which will allow for a comprehensive renovation of buildings and will result in annual energy savings. Provided energy-efficient measures and thermal modernization of houses built before the 1990s, Ukraine will be able to reduce gas consumption in the residential sector to 12 billion cubic meters in a few years.

The perspectives of further exploration in this area are to justify the cost-effectiveness of using different types of alternative fuel in rural houses.

\section{References (in language original)}

$\begin{array}{crllllll}1 . & \text { Бараннік } & \text { В.О. Ефективність енергоспоживання } & \text { в державі як індикатор } \\ \text { конкурентоспроможності. } & \text { Міждержавні співставлення. Економічний вісник HTУУ }\end{array}$ http://economy.kpi.ua/files/files/3_kpi_2010_7.pdf.

2. Енергоефективність як ресурс інноваційного розвитку: національна доповідь про стан та перспективи реалізації державної політики енергоефективності у 2008 році / С.Ф. Єрмілов, В. М. Геєць, Ю. П. Ященко та ін. К.: НАЕР, 2009. 93 с.

3. Микитенко В. В. Енергоефективність національної економіки: соціально-економічні аспекти. Вісник НАН Украӥни. 2006. № 10. С. 17-26.

4. Суходоля О.М. Аналіз законодавства та державної політики енергозбереження в Україні. ЕСКО. 2006. № 4. С.5-9.

5. Денисюк С.П. Особливості реалізації політики енергоефективності - пріоритети України. Енергетика: економіка, технологї̈, екологія. 2013. № 3. С. 7-19.

6. Hamilton, I.G., Summerfield, A.J., Shipworth, D., et al. Energy efficiency uptake and energy savings in English houses: A cohort study. Energy and Buildings. 2016. 118. P. 259-276. doi: 10.1016/j.enbuild.2016.02.024

7. Coyne, B., Lyons, S. \& McCoy, D. The effects of home energy efficiency upgrades on social housing tenants: evidence from Ireland. Energy Efficiency. 2018. Volume 11, Issue 8, P. 2077-2100. https://doi.org/10.1007/s12053-018-9688-7 
8. Lawrence, R., and Keime, C. Bridging the gap between energy and comfort: Post-occupancy evaluation of two higher-education buildings in Sheffield. Energy Build. 2016.130, P. 651-666. doi: 10.1016/j.enbuild.2016.09.001

9. Lin, B., Liu, Y., Wang, Z., Pei, Z., and Davies, M. Measured energy use and indoor environment quality in green office buildings in China. Energy Build. 2016. 129. P. 9-18. doi: 10.1016/j.enbuild.2016.07.057

10. Elsharkawy, H. and Rutherford, P. Energy-efficient retrofit of social housing in the UK: Lessons learned from a Community EnergySaving Programme (CESP) in Nottingham. Energy and Buildings. 2018. Volume 172. P. 295-306. https://doi.org/10.1016/j.enbuild.2018.04.067

11. Serrano-Lanzarote, B., Ortega-Madrigal, L., García-Prieto-Ruiz, A., Soto-Francés, L. and SotoFrancés, V.-M. Strategy for the energy renovation of the housing stock in Comunitat Valenciana (Spain). Energy and Buildings. 2016. Volume 132. P. 117-129. https://doi.org/10.1016/j.enbuild.2016.06.087

12. Villca-Pozo, M. and Gonzales-Bustos, J.-P. Tax incentives to modernize the energy efficiency of the housing in Spain. Energy Policy. 2019. Volume 128. P. 530-538. https://doi.org/10.1016/j.enpol.2019.01.031

13. Завора Т.М., Свистун Л.А., Худолій Ю.С. Концептуальні основи формування житлової політики на засадах енергоефективності та енергозбереження. Енергоефективність економіки: проблеми сьогодення та майбутнього: кол. монографія / за заг. ред. В.Я. Чевганової. Полтава: ПолтНТУ. 2017. С. 145160.

14. Термомодернізація житлового фонду: організаційний, юридичний, соціальний, фінансовий i технічний аспекти: Практичний посібник. Видання 3-те, актуалізоване / за заг. ред. В.Бригілевича. Львів, 2016. $220 \mathrm{c}$.

15. Самойлик Ю.В. Розвиток сільських територій як пріоритет соціально-економічної стратегії держави. Економіка і регіон. Науковий вісник Полтавського національного технічного університету ім. Ю. Кондратюка. 2012. № 4 (35). С. 140 - 145.

16. Житловий фонд України. Статистичний збірник. Державна служба статистики Украӥни. Відповідальний за випуск О.О. Кармазіна. К. 2019. 90 с. URL: www.ukrstat.gov.ua

17. Житловий фонд України. Статистичний збірник. Державна служба статистики Украӥни. Відповідальний за випуск О.О. Кармазіна. К. 2018. 92 c. URL: www.ukrstat.gov.ua

18. Житловий фонд України. Статистичний збірник. Державна служба статистики Украӥни. Відповідальний за випуск О.О. Кармазіна. К. 2017. 73 с. URL: www.ukrstat.gov.ua

19. Житловий фонд України. Статистичний збірник. Державна служба статистики Украӥни. Відповідальний за випуск О.О. Кармазіна. К. 2016. 79 с. URL: www.ukrstat.gov.ua

20. Житловий фонд України. Статистичний збірник. Державна служба статистики України. Відповідальний за випуск О.О. Кармазіна. К. 2015. 90 с. URL: www.ukrstat.gov.ua

21. Житловий фонд України. Статистичний збірник. Державна служба статистики Украӥни. Відповідальний за випуск I.В. Калачова. К. 2012. 371 c. URL: www.ukrstat.gov.ua

22. Житловий фонд України. Статистичний збірник. Державна служба статистики України. Відповідальний за випуск I.В. Калачова. К. 2011. 375 c. URL: www.ukrstat.gov.ua

23. Статистична інформація. Державний комітет статистики Украӥни. URL:

http://www.ukrstat.gov.ua

24. В Україні близько 90\% багатоповерхівок потребують термомодернізації. URL: http://www.nova.poltava.ua/v-ukraïni-blizko-90-bagatopoverxivok-potrebuyut-termomodernizacii//

25. Національний план дій 3 енергоефективності на період до 2020 року. Кабінет міністрів Украӥни. URL: http://saee.gov.ua/sites/default/files/documents/nats-plan-052014.doc

26. Офіційний сайт Energoinvest (сучасні технології опалення). URL:

http://www.energoinvest.com.ua/

27. Latest developments of the ESCO industry across Europe. 2017. URL:

https://www.eceee.org/library/conference_proceedings/eceee_Summer_Studies/2017/

28. Nearly zero-energy buildings. European

https://ec.europa.eu/energy/en/topics/energy-efficiency/buildings/nearly-zero-energy-buildings.

29. A Common Definition for Zero Energy Buildings" (2015). US Department of Energy. URL: https://www.energy.gov/sites/prod/files/2015/09/f26/A\%20Common\%20Definition $\% 20$ for\%20Zero\%20Energy\%20Buildings.pdf.

30. Стандарты энергоэффективности в

http://www.kz.beeca.net/biblioteka/ee-teplosnabzhenii/publikacii/252.

31. EPBD Directive 2010/31/EU on the energy performance of buildings. URL: http://www.rehva.eu/en/epbd.

\section{References}

1. Barannik V. (2010). Energy efficiency in the state as an indicator of competitiveness. Interstate comparison. Ekonomichnyj visnyk NTUU «KPI» (Economic bulletin of NTUU „KPI”). Retrieved from: http://economy.kpi.ua/files/files/3_kpi_2010_7.pdf.

2. Yermilov, S. F., Heiets, V. M., Yashchenko, Yu. P. (2009). Energy Efficiency as a Resource of Innovative Development: National Report on the Status and Perspectives of Implementing the State Energy Efficiency Policy in 2008. Kyiv: NAER.

3. Mykytenko V. (2006). Energy efficiency of the national economy: socio-economic aspects. Visnyk NAN Ukrainy (Bulletin of the National Academy of Sciences of Ukraine), № 10, 17-26.

4. Sukhodolia O. (2006). Analysis of Energy Saving Legislation and State Policy in Ukraine. ESCO (ESCO), № 4, 5-9. 
5. Denysyuk S. (2013). Features of implementation of energy efficiency policy are priorities of Ukraine. Enerhetyka: ekonomika, tekhnolohii, ekolohiia (Energy: Economics, Technologies, Ecology), № 3, 7-19.

6. Hamilton, I.G., Summerfield, A.J., Shipworth, D., et al. (2016). Energy efficiency uptake and energy savings in English houses: A cohort study. Energy and Buildings, 118, 259-276. doi: 10.1016/j.enbuild.2016.02.024

7. Coyne, B., Lyons, S. \& McCoy, D. (2018). The effects of home energy efficiency upgrades on social housing tenants: evidence from Ireland. Energy Efficiency, Volume 11, Issue 8, 2077-2100. https://doi.org/10.1007/s12053-018-9688-7

8. Lawrence, R., \& Keime, C. (2016). Bridging the gap between energy and comfort: Post-occupancy evaluation of two higher-education buildings in Sheffield. Energy Build, 130, 651-666. doi: 10.1016/j.enbuild.2016.09.001

9. Lin, B., Liu, Y., Wang, Z., Pei, Z., \& Davies, M. (2016). Measured energy use and indoor environment quality in green office buildings in China. Energy Build, 129, 9-18. doi: 10.1016/j.enbuild.2016.07.057

10. Elsharkawy, H. \& Rutherford, P. (2018). Energy-efficient retrofit of social housing in the UK: Lessons learned from a Community EnergySaving Programme (CESP) in Nottingham. Energy and Buildings, Volume 172, 295-306. https://doi.org/10.1016/j.enbuild.2018.04.067

11. Serrano-Lanzarote, B., Ortega-Madrigal, L., García-Prieto-Ruiz, A., Soto-Francés, L. \& Soto-Francés, V.-M. (2016). Strategy for the energy renovation of the housing stock in Comunitat Valenciana (Spain). Energy and Buildings, Volume 132, 117-129. https://doi.org/10.1016/j.enbuild.2016.06.087

12. Villca-Pozo, M. \& Gonzales-Bustos, J.-P. (2019). Tax incentives to modernize the energy eficiency of the housing in Spain. Energy Policy, Volume 128, 530-538. https://doi.org/10.1016/j.enpol.2019.01.031

13. Zavora T., Svystun L., Khudolii Y. (2017). Conceptual bases for housing policy formulation based on energy efficiency and energy conservation. In V. Chevganova (Eds.), Economic aspects of energy conservation: problems and ways of their solution: collective monograph (pp.145 - 160). Poltava: PoltNTU.

14. Bryhilevych V. (Eds.). (2016). Thermo modernization of housing stock: organizational, legal, social, financial and technical aspects: practical issue, third ed. Lviv.

15. Samoilyk Iu. (2012). Rural development as a priority of the socio-economic strategy of the state. Ekonomika i rehion. Naukovyj visnyk Poltavs'koho natsional'noho tekhnichnoho universytetu im. Yu. Kondratiuka (Economy and region. Scientific Bulletin of Poltava National Technical Y. Kondratyuk University), № 4 (35), 140 - 145. 16. State Statistics Service of Ukraine. (2019). Housing Fund of Ukraine. Statistical collection, 90. Retrieved from: www.ukrstat.gov.ua

17. State Statistics Service of Ukraine. (2018). Housing Fund of Ukraine. Statistical collection, 92. Retrieved from: www.ukrstat.gov.ua

18. State Statistics Service of Ukraine. (2017). Housing Fund of Ukraine. Statistical collection, 73.

Retrieved from: www.ukrstat.gov.ua

19. State Statistics Service of Ukraine. (2016). Housing Fund of Ukraine. Statistical collection, 79.

Retrieved from: www.ukrstat.gov.ua

20. State Statistics Service of Ukraine. (2015). Housing Fund of Ukraine. Statistical collection, 90.

Retrieved from: www.ukrstat.gov.ua

21. State Statistics Service of Ukraine. (2012). Housing Fund of Ukraine. Statistical collection, 371.

Retrieved from: www.ukrstat.gov.ua

22. State Statistics Service of Ukraine. (2011). Housing Fund of Ukraine. Statistical collection, 375.

Retrieved from: www.ukrstat.gov.ua

23. State Statistics Committee of Ukraine. (2018). Retrieved from: http://www.ukrstat.gov.ua/

24. In Ukraine, about $90 \%$ of high-rise buildings require thermo modernisation (2016). Retrieved from: http://www.nova.poltava.ua/v-ukraïni-blizko-90-bagatopoverxivok-potrebuyut-termomodernizacii//.

25. Cabinet of Ministers of Ukraine. (2014). National Energy Efficiency Action Plan for 2020. Retrieved from: http://saee.gov.ua/sites/default/files/documents/nats-plan-052014.doc

26. Web sait Energoinvest (modern heating technologies). Retrieved from:

http://www.energoinvest.com.ua/

27. Latest developments of the ESCO industry across Europe (2017). Retrieved from: https://www.eceee.org/library/conference_proceedings/eceee_Summer_Studies/2017/

28. European Commission. Nearly zero-energy buildings. Retrieved from: https://ec.europa.eu/energy/en/topics/energy-efficiency/buildings/nearly-zero-energy-buildings.

29. US Department of Energy (2015). A Common Definition for Zero Energy Buildings. Retrieved from: https://www.energy.gov/sites/prod/files/2015/09/f26/A\%20Common\%20Definition

$\% 20$ for\%20Zero\%20Energy\%20Buildings.pdf.

30. Energy Efficiency Standards in Europe and Germany, ESCO. (2013). Energy service (8). Retrieved from: http://www.kz.beeca.net/biblioteka/ ee-teplosnabzhenii/publikacii/252.

31. EPBD Directive 2010/31/EU on the energy performance of buildings. Retrieved from: http://www.rehva.eu/en/epbd.

\section{Самойлик Юлія Василівна}

д.е.н., доцент, доцент кафедри економіки підприємства, Полтавська державна аграрна академія, м. Полтава, Україна iuliia.samoilyk@gmail.com

\section{Свистун Людмила Анатоліївна}

к.е.н., доцент, доцент кафедри фінансів і банківської справи, 
Полтавський національний технічний університет

імені Юрія Кондратюка, с. Полтава, Україна

svmila308@gmail.com

\title{
ПЕРСПЕКТИВИ ПІДВИЩЕННЯ РІВНЯ ЕНЕРГОЕФЕКТИВНОСТІ СІЛЬСЬКОГО ЖИТЛОВОГО ФОНДУ
}

\begin{abstract}
Анотація
Постановка проблеми. Однією з головних світових проблем є проблема енергоефективності та енергозбереження. Україна володіє великим потенціалом енергозбереження. За урядовими оцінками, енергоспоживання у державі може бути скорочено майже удвічі за рахунок впровадження енергетично ефективних технологій в промисловості $і$ комунальному господарстві. Рівень спожсиання енергоносіїв в Україні практично втричі вищий, ніж у краӥнах СС. Отже, потенціал для розвитку ефективного використання енергї̈, зокрема у сфері експлуатації нерухомості, є дуже великим. Україна має застарілий житловий фонд, пери за все це забудови періоду 50-70-х років. Через стіни, вікна будівлі втрачають третину тепла, є значні недоліки в гідроізолячії покрівель, багаторічна експлуатація призвела до зносу інженерних мереж. Енергоємність житлово-комунальної сфери складає $31 \%$, що потребує визначення напрямів реконструкиії житлового фонду на засадах підвищення його енергоефективності й енергозбереження. Будівля, яка споживає менше енергії для забезпечення умов більшого комфорту, є більш енергоефективною. Тому у сучасних умовах подорожчання енергоресурсів використання альтернативних видів енергї для опалення будинків є вкрай актуальним.
\end{abstract}

Мета. Обтрунтування пропозицій щ⿻одо підвищення рівня енергоефективності сільських будинків, виявлення потенціалу енергоефективності у сільській місцевості, виявлення відмінностей у споживанні енергї на селі та в місті.

Методи дослідження. Системний підхід, монографічний, індукиії, економічного аналізу, порівняльного аналізу, графічний.

Результати. Виявлено тенденції та пропориії забудови міста та сільської місцевості. Визначено, щуо житловий фонд в сільській місиевості становив близько $39 \%$ від загальної забудови в Україні. Сільське розселення є нерівномірним по Україні, найбільше сільських будинків розташовано в Західному регіоні. Проведено діагностику показників енергоспожсивання в сільських будинках в розрізі регіонів України. Виявлено, шьо більшість будинків як в селі, так $і$ в місті, було збудовано в післявоєнний час та в період першої індустріальної забудови. У иі періоди норми енергоефективності суттєво відрізнялись від сучасних. Головні причини значного енергоспоживання в будинках в межах сільських територій $\epsilon$ значна зношеність конструкиій, щүілини у дверях та вікнах, низький рівень енергоефективності будівельних матеріалів того часу. У сільській місцевості майже відсутнє иентралізоване опалення. Більшість сільських будинків оснащені газовими котлами, майже стільки ж будинків використовуються пічне опалення. В основному, здійснюється комбінування ичих двох видів опалення. У динаміці спостерігається збільшення частки будинків з газовими котлами та відповідне зменшення частки будинків із пічним опаленням. Розраховано показники обсягів та вартості енергоспоживання в місті та на селі $і$ з'ясовано, щзо витрати на опалення на селі в розрахунку на 1 $\mu^{2}$ житлової площчі в середньому втричі вищі, ніж у місті, щзо підкреслює необхідність термомодернізації. Найдешевшим є пічне опалення дровами. Запропоновано механізм проведення енергоаудиту. Обтрунтовано роль суб'єктів енергоспоживання на державному та локальному рівнях. Запропоновано напрямки підвищення рівня енергоефективності в сільських будинках запропоновано

Наукова новизна. Набуло подальшого розвитку пропозиції щцодо підвищення рівня енергоефективності житла, зокрема у сільській місцевості. Уперше було проведено комплексне дослідження масштабів сільськогосподарського будівництва у взаємозв'язку з потенціалом енергозбереження в даній сфері на основі закордонного досвіду та розвитку альтернативної енергетики.

Висновки. Сучасний стан житлового фонду Украйни, зокрема в сільській місцевості, а також енергетична та економічна ситуація в краӥні вимагають якнайскорішого вирішення проблеми підвищення енергоефективності у житловому секторі. Досвід розвинутих країн вказує на необхідність державного регулювання процесів енергозбереження у сфері нерухомості та проведення відповідної иілеспрямованої політики підвищення енергоефективності експлуатацї нерухомості. Кроками украӥнського уряду у напрямі підвищення енергоефективності житлового фонду має стати ефективна діяльність спеціалізованого фонду енергоефективності з метою забезпечити стабільне фінансування проектів з модернізаиії житлових будинків, щчо дозволить провести комплексне оновлення будівель та призведе до щчорічної економї на енергоресурсах. 3 а умови проведення енергоефективних заходів та термомодернізаџії будівель, побудованих до 90-х років, Україна через кілька років зможе скоротити споживання газу у житловому секторі до 12 млрд. куб.

Ключові слова: енергоефективність, енергоспоживання, сільський будинок, енергоаудит, енергозберігаюча санаџія. 